\section{Demographic, clinical characteristics and cardiovascular disease burden in a Portuguese cohort of older chronic kidney disease patients}

Dados demográficos, características clínicas e peso da doença cardiovascular em uma coorte portuguesa de pacientes idosos com doença renal crônica

\section{Authors}

Josefina Maria Sousa Santos Lascasas ${ }^{1,2}$ iD

Isabel Fonseca ${ }^{1,2,3}$

Jorge Malheiro ${ }^{1,2}$

Sofia Santos ${ }^{1}$

Andreia Campos ${ }^{1}$

Ana Castro $^{1}$

Carla Moreira ${ }^{1}$

Sofia Correia ${ }^{1}$

Idalina Beirão ${ }^{1,2}$

Luísa Lobato ${ }^{1,2}$

António Cabrita ${ }^{1}$

${ }^{1}$ Centro Hospitalar do Porto, Hospital de Santo António, Departamento de Nefrologia, Porto, Portugal.

${ }^{2}$ Universidade do Porto, Instituto de Ciências Biomédicas Abel Salazar, Unidade Multidisciplinar de Investigação Biomédica, Porto, Portugal.

${ }^{3}$ Universidade do Porto, Instituto de Saúde Pública, Porto, Portugal.

Submitted on: 03/30/2018. Approved on: 09/23/2018.

\section{Correspondence to:}

Josefina Maria Sousa Santos

Lascasas.

E-mail: josefina.sts@gmail.com

DOI: 10.1590/2175-8239-JBN-2018-0120

\section{Aвstract}

Introduction: Chronic kidney disease (CKD) is an independent risk factor for several unfavorable outcomes including cardiovascular disease (CVD), particularly in the elderly, who represent the most rapidly growing segment of the end-stage kidney disease (ESKD) population. Portugal has the highest European unadjusted incidence and prevalence rates of ESKD. In 2012, we started to follow a cohort of elderly CKD patients, we describe their baseline characteristics, risk profile, and cardiovascular disease burden. Methods: All CKD patients aged 65 years and older referred to our department during 2012 were enrolled. Baseline data included: demographic, CKD stage, medication, comorbid conditions. Estimated glomerular filtration rate (eGFR) was calculated by the CKD-EPI formula. Results: A total of 416 patients, $50 \%$ referred by primary care physicians, aged $77 \pm 7$ years, $52 \%$ male, with a median eGFR of 32 $\mathrm{mL} / \mathrm{min} / 1.73 \mathrm{~m}^{2}$ participated in the study. Fifty percent had diabetes (DM), $85 \%$ dyslipidemia, 96\% hypertension; $26 \%$ were current/former smokers, and $24 \%$ had a body mass index $>30 \mathrm{~kg} / \mathrm{m}^{2}$. The prevalence of CVD was $62 \%$ and higher in stage 4-5 patients; in diabetics, it gradually increased with CKD progression (stage $3 a<$ stage $3 b<$ stage $4-5)(39,58$, $82 \% ; p<0.001)$. Conclusions: At baseline, our CKD elderly cohort had a higher burden of CVD. The prevalence of CVD was greater than in other European CKD cohorts. Lower level of eGFR was associated with a greater burden of CVD and was more pronounced in diabetics, highlighting the importance of strategically targeting cardiovascular risk reduction in these patients.

Keywords: Renal Insufficiency, Chronic; Cardiovascular Diseases; Aged.

\section{Resumo}

Introdução: Doença renal crônica (DRC) é fator de risco independente para vários desfechos desfavoráveis, incluindo doença cardiovascular (DCV), particularmente em idosos, o segmento de crescimento mais rápido da população com doença renal terminal (DRT). Portugal tem a maior incidência europeia não-ajustada e a maior prevalência de DRT. Neste artigo caracterizamos uma coorte de idosos com DRC, referenciados para a nefrologia, com particular ênfase para o risco e carga de doença cardiovascular. Métodos: Foram incluídos todos os pacientes com DRC com 65 anos ou mais encaminhados ao nosso departamento em 2012. Os dados basais incluíram: demografia, estágio da DRC, medicação e comorbidades. A taxa de filtração glomerular (TFGe) foi calculada pela fórmula CKD-EPI. Resultados: Metade dos 416 pacientes incluídos foram encaminhados por médicos da atenção primária; sua idade era $77 \pm 7$ anos; $52 \%$ eram homens; a TFGe mediana era de $32 \mathrm{~mL} / \mathrm{min} / 1,73$ $\mathrm{m}^{2}$. Metade tinha diabetes (DM), $85 \%$ dislipidemia, 96\% hipertensão; $26 \%$ eram fumantes atuais/ antigos; $24 \%$ tinham índice de massa corporal $>30 \mathrm{~kg} / \mathrm{m}^{2}$. A prevalência de DCV foi de $62 \%$, sendo maior entre pacientes nos estágios 4-5; em diabéticos, aumentou gradualmente com a progressão da DRC (estágio 3a < estágio 3b < estágio $4-5)(39 \%, 58 \%, 82 \%$; $p<0,001)$. Conclusões: A coorte de idosos com DRC apresentava inicialmente maior carga de DCV. A prevalência de DCV foi maior que em outras coortes europeias com DRC. Níveis menores de TFGe foram associados a carga maior de DCV e foram mais pronunciados entre diabéticos, destacando a importância de objetivar estrategicamente a redução do risco cardiovascular nesses pacientes.

Palavras-chave: Insuficiência Renal Crônica; Doenças Cardiovasculares; Idoso. 


\section{INTRODUCTION}

Chronic kidney disease (CKD) has emerged as a serious public health problem, as shown by the increase in overall and cardiovascular mortality and the growing incidence and prevalence of end-stage kidney disease (ESKD), with patients requiring renal replacement therapy and leading to very high health-care costs $^{1}$. Parallel to this, the prevalence of CKD is higher in older people, and patients over 65 years of age represent the most rapidly growing segment of the ESKD population in wealthier countries ${ }^{2,3}$.

Portugal has the highest unadjusted incidence and prevalence of ESKD among European countries ${ }^{4}$ and $62.3 \%$ of the incident dialysis patients in 2016 were over 65 years with a mean age of prevalent patients of 67 years $^{5}$.

CKD is associated with increased prevalence of both traditional (e.g., hypertension) and nontraditional cardiovascular risk factors (e.g., proteinuria, elevated uric acid levels, hyperhomocysteinemia), and predisposing factors to microvascular disease (e.g., inflammation, inflammation, abnormal calcium-phosphate homeostasis $)^{6,7}$, with studies confirming that in the elderly, even in early CKD stages, cardiovascular mortality outweighs the risk of progression to ESKD ${ }^{8}$.

In 2012, we started to follow a cohort of elderly patients until the occurrence of the first event (ESKD or death $)^{9}$. In this report we describe their baseline demographic and clinical characteristics, with particular emphasis for the cardiovascular disease burden, to define improved strategies of care.

\section{Patients and methods}

\section{STUDY DESIGN AND POPULATION}

This study included consecutive CKD (non-dialyzed and non-transplanted) patients aged $\geq 65$ years, newly referred to our outpatient department in Centro Hospitalar do Porto (CHP), within January 1, 2012 and December 31, 2012. CHP is a tertiary-care hospital that serves a diverse population of 500000 inhabitants in the North region of the country.

Data collection was conducted by nephrologists using electronic case report forms. Reporting of cardiovascular disease was based on both the patients' self report and review of their medical records by trained staff on the same date of the baseline interview. The study was performed in accordance with the Declaration of Helsinki and approved by the Institutional Review Board of CHP.

Baseline date included sex, age, body mass index (BMI), CKD stage, proteinuria, medication, and comorbid conditions, such as diabetes, dyslipidemia, hypertension, smoking status, and cardiovascular disease. Cardiovascular disease was defined as the history of at least one of the following: cardiac disease, cerebrovascular disease, and peripheral vascular disease. Cardiac disease was defined as the history of coronary artery disease, congestive heart failure, and severe valvular heart disease with or without valvular replacement. Criteria for the diagnosis of coronary artery disease included previous myocardial infarction, angina pectoris, coronary artery bypass grafting, or percutaneous transluminal coronary angioplasty with or without stent implantation. Cerebrovascular disease included previous transient ischemic attack, stroke, or cerebral hemorrhage. Peripheral artery disease was defined as the presence of intermittent claudication, need of peripheral revascularization, or amputation.

All diabetic patients met the classification criteria established by the American Diabetes Association. Hypertension was considered if the patient had systolic blood pressure $(\mathrm{BP})>140 \mathrm{mmHg}$ or diastolic BP $>90 \mathrm{mmHg}$ or need for antihypertensive drugs. Dyslipidemia included total serum cholesterol $>200$ $\mathrm{mg} / \mathrm{dL}$, or triglycerides $>150 \mathrm{mg} / \mathrm{dL}$, or high-density lipoprotein (HDL) cholesterol $<40 \mathrm{mg} / \mathrm{dL}$ in males and $<48 \mathrm{mg} / \mathrm{dL}$ in females, or low-density lipoprotein (LDL) cholesterol $>100 \mathrm{mg} / \mathrm{dL}$, or need for lipidlowering drugs.

Glomerular filtration rate was estimated (eGFR) using the Chronic Kidney Disease Epidemiology (CKD-EPI) 2009 creatinine equation ${ }^{10}$. Etiological diagnosis of CKD was based on the patient's history, kidney ultrasound, and kidney biopsy, when available. Blood and urine routine measurements were collected: hemoglobin, serum albumin, urea nitrogen, creatinine, calcium, phosphorus, intact parathyroid hormone (PTH), glucose, hemoglobin A1c, uric acid, lipid profile, iron, unsaturated iron binding capacity, ferritin, and urine protein-to-creatinine ratio (uPCr) in spot urine sample.

Cognitive status was evaluated and screened using the Mini Mental State Examination (MMSE) ${ }^{11}$, classified as cognitive impairment if the score was 23 or 
lower. Functional dependency was defined as the requirement of assistance in the activities of daily living, and classified as totally dependent, partially dependent, and autonomous.

A modified version of the Charlson comorbidity index $(\mathrm{mCCI})^{12}$ i.e., subject's age and presence or absence of kidney disease was excluded, was calculate to assess severity of comorbidities.

\section{STATISTICAL ANALYSIS}

Baseline characteristics are described using mean \pm standard deviation or median with interquartile ranges for continuous variables, while categorical data are presented as numbers and percentages. Cardiovascular disease burden was compared between CKD stages by Chi-squared test for trend for categorical variables. Statistical analyses were performed using SPSS version 22.0. P-value $<0.05$ was considered statistically significant.

\section{RESULTS}

\section{BASELINE DEMOGRAPHIC AND CLINICAL CHARACTERISTICS}

From a total of 848 patients newly referred to our Nephrology department during 2012, 416 of them were 65 years and older. Of these, all were Caucasians, $52 \%$ were male, with a mean age of 77 years, and $36 \%$ of them were aged 80 years or more. About $50 \%(\mathrm{n}=206)$ of the patients were diabetic. The majority $(85 \%)$ of the study population came from urban areas.

Their baseline characteristics, divided by gender and by the presence or absence of diabetes are summarized in Table 1. Fifty percent of the patients were referred by primary care physicians. At baseline, they had a median serum creatinine of $1.6 \mathrm{mg} / \mathrm{dL}$ and a median eGFR of $32 \mathrm{~mL} / \mathrm{min}$ per $1.73 \mathrm{~m}^{2}$. The most frequent etiologies of renal disease were ischemic nephropathy $(\mathrm{n}=159 ; 38 \%)$ and diabetic nephropathy ( $\mathrm{n}=106 ; 26 \%)$; unknown causes of renal disease were $55(13 \%)$. Only $4 \%(n=17)$ of the patients had a renal biopsy.

Most of patients were nonsmokers ( $\mathrm{n}=307$; $74 \%)$. The proportion of current or former smokers was highest in men with $(\mathrm{n}=52 ; 46 \%)$ and without diabetes $(n=50 ; 47 \%)$. Overall, $24 \%(n=101)$ of enrolled patients were obese $\left(\mathrm{BMI}>30 \mathrm{~kg} / \mathrm{m}^{2}\right)$. The BMI ranged from a mean value of $25.7 \pm 4.1 \mathrm{~kg} / \mathrm{m}^{2}$ in men without diabetes to $29.5 \pm 5.5 \mathrm{~kg} / \mathrm{m}^{2}$ in women with diabetes.

About $96 \%(n=400)$ of the patients presented hypertension, with a mean BP of 141/72 $\mathrm{mmHg}$. In approximately $30 \%$ of the patients it was $<130 / 80$ $\mathrm{mmHg}$ and in approximately $50 \%$ it was $<140 / 90$ $\mathrm{mmHg}$; men with diabetes were the group with worst BP control (BP goal < 130/80 mmHg). About 50\% (n $=207$ ) of the patients were receiving two or more antihypertensive drugs (excluding diuretics), and 14\% $(\mathrm{n}=58)$ were under three or more antihypertensive drugs. Inhibitors of the renin angiotensin system were the drugs most frequently used $(\mathrm{n}=293 ; 70 \%$ of the patients): angiotensin-converting enzyme (iECA) inhibitors in $33 \%(\mathrm{n}=137)$, angiotensin II receptor blockers (ARB) in $41 \%(\mathrm{n}=172)$, and combined iECA and ARB in $4 \%(n=16)$ of the patients. The use of these agents was more frequent in men with diabetes $(77 \%)$. About $71 \%(n=296)$ of the patients were on diuretics.

Dyslipidemia was present in $85 \%$ of the patients $(\mathrm{n}=354)$ and $60 \%(\mathrm{n}=248)$ were under lipid-lowering medication. Dyslipidemia was more prevalent in patients with diabetes $(\mathrm{n}=189 ; 92 \%)$.

An active or previous malignancy was present in $15 \%(n=62)$ of patients. About $25 \%(n=105)$ of the patients had a high comorbidity index (mCCI score $\geq$ $5)$, particularly men with diabetes $(\mathrm{n}=55 ; 49 \%)$.

About $50 \%(n=206)$ of the patients were diabetic, but in only $51 \%(\mathrm{n}=106)$ of them, diabetic nephropathy was considered the etiology of renal disease; $48 \%$ of those patients with etiologies of CKD other than diabetic nephropathy had diabetes. When we analyzed baseline characteristics in patients with diabetes separately for patients with and without diabetic nephropathy in comparison to patients without diabetes (Supplementary Table S1), clinical and demographic data were very similar in the three groups, with the exception of a higher systolic BP, the use of more antihypertensive drugs, higher prevalence of dyslipidemia, and higher proteinuria level in those with presumed diabetic nephropathy.

Regarding functional dependency, $6 \%(n=25)$ of the patients were totally dependent, and $38 \%$ ( $\mathrm{n}=$ 158 ) were partially dependent with no difference between the groups. Cognitive impairment was present in $12 \%(\mathrm{n}=50)$ of the patients, with no difference between the groups. 


$\begin{array}{lr}\text { Male } & \text { Female } \\ \mathrm{n}=218 & \mathrm{n}=198\end{array}$

\begin{tabular}{|c|c|c|c|c|c|}
\hline & $\begin{array}{c}\text { Total } \\
\mathrm{n}=416\end{array}$ & $\begin{array}{c}\text { Diabetics } \\
\mathrm{n}=112\end{array}$ & $\begin{array}{l}\text { Non-Diabetics } \\
\qquad n=106\end{array}$ & $\begin{array}{c}\text { Diabetics } \\
\mathrm{n}=94\end{array}$ & $\begin{array}{c}\text { Non-Diabetics } \\
n=104\end{array}$ \\
\hline Age (years), mean;SD & $76.9 \pm 7.4$ & $75.2 \pm 7.1$ & $77.6 \pm 7.6$ & $75.9 \pm 7.2$ & $78.8 \pm 7.2$ \\
\hline Age $\geq 80$ years, $n(\%)$ & $149(36)$ & $28(25 \%)$ & $43(41 \%)$ & $30(32 \%)$ & $49(47 \%)$ \\
\hline $\begin{array}{l}\text { eGFR EPI }\left(\mathrm{ml} / \mathrm{min} / 1.73 \mathrm{~m}^{2}\right) \\
\text { median;IQR }\end{array}$ & 32 [23-42] & 30 [22-39] & $27[21-37]$ & 33 [25-43] & 34 [27-47] \\
\hline $\begin{array}{l}\text { Serum creatinine (mg/dL), } \\
\text { median;IQR }\end{array}$ & $1.6[1.3-2.0]$ & $1.7[1.3-2.1]$ & $1.7[1.4-2.2]$ & $1.4[1.2-1.9]$ & 1.4 [ 1.1-1.8] \\
\hline \multicolumn{6}{|l|}{ CKD Stage, $\mathrm{n}(\%)$} \\
\hline Stage 1 & $6(1.4)$ & $0(0.0)$ & $0(0.0)$ & $3(3.2)$ & $3(2.9)$ \\
\hline Stage 2 & $33(7.9)$ & $11(9.8)$ & $8(7.5)$ & $8(8.5)$ & $6(5.8)$ \\
\hline Stage $3 a$ & $46(11.0)$ & $9(8.0)$ & $10(9.4)$ & $9(9.6)$ & $18(17.3)$ \\
\hline Stage 3b & $139(33.4)$ & $36(32.1)$ & $24(22.6)$ & $37(39.4)$ & $42(40.4)$ \\
\hline Stage 4 & $158(38.0)$ & $43(38.4)$ & $50(47.2)$ & $33(35.1)$ & $32(30.8)$ \\
\hline Stage 5 & $34(8.2)$ & $13(11.6)$ & $14(13.2)$ & $4(4.3)$ & $3(2.9)$ \\
\hline \multicolumn{6}{|l|}{ Referral, n (\%) } \\
\hline Primary care & 207 (49.8) & $54(48.2)$ & $50(47.2)$ & $49(52.1)$ & $54(51.9)$ \\
\hline Hospital appointment & $191(45.9)$ & $54(48.2)$ & $52(49.1)$ & $41(43.6)$ & $44(42.3)$ \\
\hline Other & $18(4.3)$ & $4(3.6)$ & $4(3.8)$ & $4(4.3)$ & $6(5.8)$ \\
\hline \multicolumn{6}{|l|}{ Renal disease etiology, n (\%) } \\
\hline Ischemic nephropathy & $159(38.2)$ & $36(32.1)$ & $52(49.1)$ & $22(23.4)$ & $49(47.1)$ \\
\hline Diabetic nephropathy & $106(25.5)$ & $62(55.4)$ & $0(0.0)$ & $44(46.8)$ & $0(0.0)$ \\
\hline Glomerulonephritis & $16(3.8)$ & $1(0.9)$ & $8(7.5)$ & $3(3.2)$ & $4(3.8)$ \\
\hline Polycystic kidney disease & $7(1.7)$ & $1(0.9)$ & 4 (3.8) & $1(1.1)$ & $1(1.0)$ \\
\hline Miscellaneous & $73(17.5)$ & $9(8.0)$ & $25(23.6)$ & $13(13.8)$ & $26(25.0)$ \\
\hline Unknown & $55(13.2)$ & $3(2.7)$ & $17(16.0)$ & $11(11.7)$ & $24(23.1)$ \\
\hline $\mathrm{mCCl}$ score $\geq 5, \mathrm{n}(\%)$ & $105(25.2)$ & $55(49.1)$ & $14(13.2)$ & $31(32.9)$ & $5(4.8)$ \\
\hline $\mathrm{BMI}\left(\mathrm{kg} / \mathrm{m}^{2}\right)$, mean;SD & $27.3 \pm 4.8$ & $27.1 \pm 4.9$ & $25.7 \pm 4.1$ & $29.5 \pm 5.5$ & $27.0 \pm 4.6$ \\
\hline $\mathrm{BMI}>30\left(\mathrm{~kg} / \mathrm{m}^{2}\right), \mathrm{n}(\%)$ & $101(24.4)$ & 19 (16.9) & $13(12.3)$ & $43(45.7)$ & $23(22.1)$ \\
\hline $\mathrm{BMI}>25$ to $\leq 30\left(\mathrm{~kg} / \mathrm{m}^{2}\right), \mathrm{n}(\%)$ & $174(42.0)$ & $60(53.6)$ & $43(40.5)$ & $31(33.0)$ & $44(42.3)$ \\
\hline $\mathrm{BMI} \leq 25\left(\mathrm{~kg} / \mathrm{m}^{2}\right), \mathrm{n}(\%)$ & $139(33.6)$ & $33(29.5)$ & $50(47.2)$ & $20(21.3)$ & $37(35.6)$ \\
\hline Current smokers, n (\%) & $22(5.3)$ & $8(7.1)$ & $10(9.4)$ & $2(2.1)$ & $2(1.9)$ \\
\hline Former smokers, n (\%) & $87(20.9)$ & 44 (39.3) & 40 (37.8) & $2(2.1)$ & $1(1.0)$ \\
\hline Never smokers, n (\%) & $307(73.8)$ & $60(53.6)$ & $56(52.8)$ & 90 (95.8) & $101(97.1)$ \\
\hline SBP $(\mathrm{mm} \mathrm{Hg})$, mean;SD & $140.9 \pm 24.1$ & $142.7 \pm 22.6$ & $139.4 \pm 22.1$ & $140.9 \pm 26.7$ & $140.5 \pm 25.2$ \\
\hline $\mathrm{DBP}(\mathrm{mm} \mathrm{Hg})$, mean;SD & $71.7 \pm 12.5$ & $71.8 \pm 11.4$ & $72.5 \pm 12.4$ & $71.3 \pm 12.5$ & $71.3 \pm 13.9$ \\
\hline MAP (mmHg), mean;SD & $94.8 \pm 14.7$ & $95.9 \pm 13.5$ & $93.7 \pm 13.5$ & $94.7 \pm 16.2$ & $94.7 \pm 15.9$ \\
\hline $\mathrm{BP}<130 / 80 \mathrm{mmHg}, \mathrm{n}(\%)$ & $130(31.3)$ & $30(26.8)$ & $31(29.2)$ & $32(34.0)$ & $37(35.6)$ \\
\hline $\mathrm{BP}<140 / 90$ mmHg, n (\%) & $198(47.6)$ & $48(42.9)$ & $49(46.2)$ & $49(52.1)$ & $52(50.0)$ \\
\hline Antihypertensive $\geq 3, \mathrm{n}(\%)$ & $58(13.9)$ & 20 (17.9) & $16(15.1)$ & $10(10.6)$ & $12(11.5)$ \\
\hline $\begin{array}{l}\text { Renin-angiotensin blockade, } \\
\mathrm{n}(\%)\end{array}$ & $293(70.4)$ & $86(76.8)$ & $72(67.9)$ & $65(69.1)$ & 70 (67.3) \\
\hline Dyslipidemia, n (\%) & $354(85)$ & $104(92.9)$ & $81(76.4)$ & $85(90.4)$ & $84(80.8)$ \\
\hline Lipid-lowering medication, n (\%) & $248(59.6)$ & $73(65.2)$ & $60(56.6)$ & $54(57.4)$ & $61(58.7)$ \\
\hline Albumin $(\mathrm{g} / \mathrm{dL})$ & $4.09 \pm 0.50$ & $4.08 \pm 0.49$ & $4.20 \pm 0.46$ & $3.98 \pm 0.55$ & $4.08 \pm 0.49$ \\
\hline
\end{tabular}


Continued Table 1.

\begin{tabular}{lccccc}
\hline Uric acid (mg/dL), mean;SD & $7.3 \pm 2.2$ & $7.3 \pm 2.1$ & $7.3 \pm 2.2$ & $7.1 \pm 2.3$ & $7.2 \pm 2.4$ \\
\hline $\begin{array}{l}\text { Total cholesterol } \\
\text { (mg/dL),mean;SD }\end{array}$ & $180 \pm 49$ & $176 \pm 46$ & $173 \pm 45$ & $178 \pm 50$ & $192 \pm 53$ \\
\hline HDL (mg/dL), mean;SD & $48 \pm 14$ & $45 \pm 13$ & $50 \pm 16$ & $44 \pm 12$ & $52 \pm 15$ \\
\hline LDL (mg/dL), mean;SD & $105 \pm 40$ & $102 \pm 38$ & $101 \pm 37$ & $104 \pm 42$ & $113 \pm 42$ \\
\hline Hemoglobin (g/dL), mean;SD & $12.1 \pm 1.8$ & $12.4 \pm 1.7$ & $12.7 \pm 2.1$ & $11.3 \pm 1.5$ & $11.9 \pm 1.5$ \\
Hemoglobin < 11g/dL, n (\%) & $110(26.4)$ & $23(20.5)$ & $26(24.5)$ & $36(38.3)$ & $25(24.0)$ \\
\hline TSAT (\%), mean;SD & $22 \pm 10$ & $22 \pm 10$ & $25 \pm 11$ & $18 \pm 9$ & $23 \pm 11$ \\
\hline Ferritin (ng/mL), mean;SD & $245 \pm 251$ & $246 \pm 269$ & $286 \pm 263$ & $188 \pm 187$ & $271 \pm 261$ \\
\hline iPTH (pg/mL), mean;SD & $125.0 \pm 90.3$ & $120.5 \pm 101.0$ & $134.6 \pm 81.7$ & $114.5 \pm 74.5$ & $132.2 \pm 98.6$ \\
\hline Calcium (mg/dL), mean;SD & $2.37 \pm 0.18$ & $2.36 \pm 0.16$ & $2.37 \pm 0.16$ & $2.38 \pm 0.22$ & $2.39 \pm 0.20$ \\
\hline Phosphate (mg/dL), mean;SD & $1.14 \pm 0.22$ & $1.13 \pm 0.25$ & $1.06 \pm 0.23$ & $1.18 \pm 0.21$ & $1.17 \pm 0.22$ \\
\hline uPCr (g/g), mean;SD & $1.10 \pm 2.20$ & $1.33 \pm 2.27$ & $0.72 \pm 1.48$ & $1.29 \pm 2.38$ & $0.99 \pm 2.46$ \\
\hline
\end{tabular}

Continuous variables are presented as mean \pm standard deviation or medians and interquartile ranges when appropriate. Categorical data are presented as numbers ( $\mathrm{n}$ ) of patients and percentages (\%). The number of missing values was < $1 \%$ for all parameters except to UPCr (20\%). eGFR, estimated glomerular filtration rate; mCCl, modified Charlson comorbidity index; BMI, body mass index; SBP, Systolic blood pressure; DBP, Diastolic blood pressure; MAP, Mean Arterial Pressure; HDL, high density lipoprotein; LDL, low density lipoprotein; TSAT, transferrin saturation; iPTH, intact parathyroid hormone; uPCr, urinary protein-to-creatinine ratio.

Globally, eGFR was slightly lower in men, particularly those without diabetes. The mean uPCr rate was 1.1 , higher in patients with diabetes when compared to patients without diabetes.

Most patients had a hemoglobin level $\geq 11 \mathrm{~g} / \mathrm{dL}$ $(\mathrm{n}=306 ; 74 \%)$, and the percentage of patients with transferrin saturation $<20 \%$ was $38 \%(\mathrm{n}=158)$, and ferritin level $<100$ was $25 \%(\mathrm{n}=104)$, respectively. Only $5 \%(\mathrm{n}=21)$ of the total cohort was receiving erythropoiesis stimulating agents (ESA). The percentage of patients on oral and IV iron supplementation were $10 \%(\mathrm{n}=42)$ and $0.7 \%(\mathrm{n}=3)$, respectively.

Intact parathyroid hormone was elevated in $81 \%$ (n $=337$ ) of the patients, despite good control of calciumphosphorus levels. The percentage of patients being treated with vitamin D supplementation and phosphate binders was $7 \%(\mathrm{n}=28)$ and $4 \%(\mathrm{n}=17)$, respectively.

\section{BASELINE CARDIOVASCULAR PREVALENCE}

Cardiovascular disease was present in $62 \%(\mathrm{n}=256)$ of the patients: coronary artery disease in $25 \%(\mathrm{n}=103)$, cerebrovascular disease in $24 \%(\mathrm{n}=100)$, and peripheral vascular disease in $19 \%(\mathrm{n}=77)$, respectively (Table 2$)$.
Coronary artery disease was present in 31\% ( $\mathrm{n}=$ 64 ) of the patients with diabetes, compared to $19 \%$ (n = 39) in patients without diabetes.

Previous cerebrovascular events were more frequent in men compared to women: $28 \%(\mathrm{n}=60)$ and $20 \%(n=40)$, respectively; the prevalence was only slightly higher in patients with diabetes compared to patients without diabetes: $26 \%(\mathrm{n}=53)$ and $22 \%(\mathrm{n}$ $=47)$, respectively.

Peripheral vascular disease was more prevalent in patients with diabetes compared to patients without diabetes, $24 \%(\mathrm{n}=49)$ and $13 \%(\mathrm{n}=28)$, respectively, and in men compared to women, $23 \%(\mathrm{n}=51)$ and $13 \%(n=26)$, respectively.

Stratifying the CKD stages in $3 a, 3 b$, and 4-5 the prevalence of coronary artery disease, congestive heart failure, and peripheral vascular disease were highest in stage 4-5 patients, gradually increasing with CKD progression (Figure 1). The cardiovascular disease burden associated with eGFR declining was more pronounced in patients with diabetes, compared to patients without diabetes (Table 3). 


\begin{tabular}{|c|c|c|c|c|c|}
\hline & \multirow[t]{3}{*}{$\begin{array}{c}\text { Total } \\
\mathrm{n}=416\end{array}$} & \multicolumn{2}{|c|}{$\begin{array}{c}\text { Male } \\
n=218\end{array}$} & \multicolumn{2}{|c|}{$\begin{array}{c}\text { Female } \\
\mathrm{n}=198\end{array}$} \\
\hline & & Diabetics & Non-Diabetics & Diabetics & Non-Diabetics \\
\hline & & $\mathrm{n}=112$ & $n=106$ & $\mathrm{n}=94$ & $\mathrm{n}=104$ \\
\hline Cardiovascular disease ${ }^{*}, \mathrm{n} ;(\%)$ & $256(62)$ & $74(66)$ & $65(61)$ & $60(64)$ & $57(55)$ \\
\hline Cardiac disease, n; $(\%)$ & $282(68)$ & $78(70)$ & $62(58)$ & $85(90)$ & $57(55)$ \\
\hline Coronary artery disease & $103(25)$ & $34(30)$ & $25(24)$ & $30(32)$ & $14(13)$ \\
\hline Congestive heart failure & 164 (39) & $42(38)$ & $34(32)$ & $50(53)$ & $38(37)$ \\
\hline Severe valvular heart disease & $15(4)$ & $2(2)$ & $3(3)$ & $5(5)$ & $5(5)$ \\
\hline Cerebrovascular disease, n; (\%) & $100(24)$ & $35(31)$ & $25(24)$ & $18(19)$ & $22(21)$ \\
\hline Peripheral artery disease, n; (\%) & 77 (19) & $33(29)$ & $18(17)$ & $16(17)$ & $10(10)$ \\
\hline
\end{tabular}

${ }^{*}$ Cardiovascular disease includes all patients with one or more of the following: cardiac disease, cerebrovascular and peripheral vascular disease.

Categorical data are presented as numbers $(\mathrm{n})$ of patients and percentages (\%).

Figure 1. Prevalence (\%) of individual causes of cardiovascular disease stratified by CKD stages.

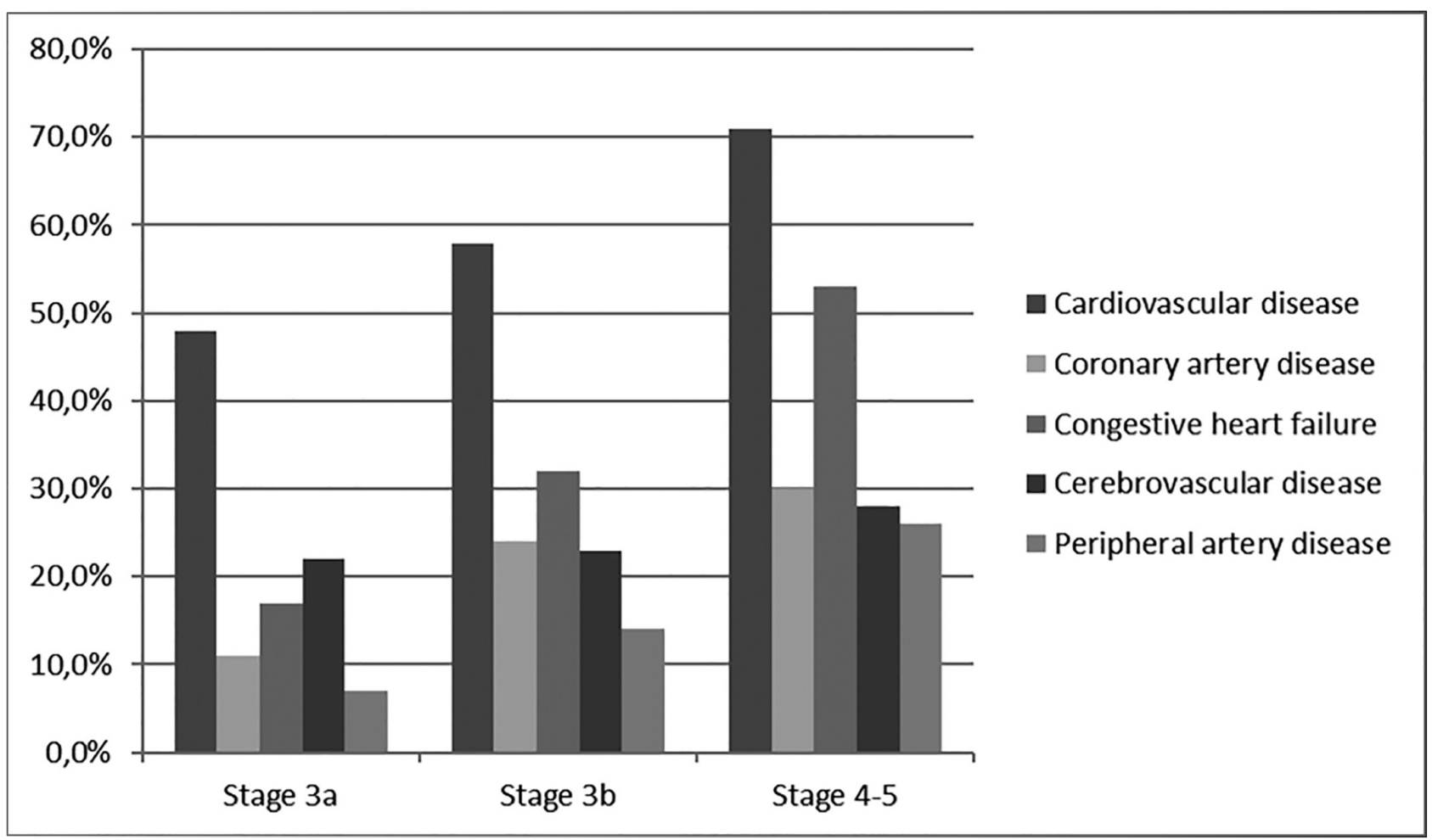

\section{Discussion}

When we designed our longitudinal cohort study, the main objective was to identify the main predictors for CKD progression and death in elderly CKD patients referred to our outpatient department ${ }^{9}$. In this report we analyzed their baseline characteristics, cardiovascular risk profile, and cardiovascular disease prevalence.
A particular characteristic of this study is that all enrolled patients were newly referred to our nephrology department. This gives us information on the baseline characteristics of the patients before they receive specific attention from the nephrologist.

In our cohort, the two most frequent causes of CKD were ischemic and diabetic nephropathy, which are considered leading causes of CKD worldwide ${ }^{13,14}$, particularly in older patients. In $13 \%$ of the patients, 


\begin{tabular}{|c|c|c|c|c|c|c|c|c|c|c|c|c|}
\hline \multirow{3}{*}{$\begin{array}{l}\text { CKD } \\
\text { Stage }\end{array}$} & \multicolumn{4}{|c|}{$\begin{array}{c}\text { Total } \\
\mathrm{n}=377\end{array}$} & \multicolumn{4}{|c|}{$\begin{array}{c}\text { Diabetics } \\
\mathrm{n}=184\end{array}$} & \multicolumn{4}{|c|}{$\begin{array}{l}\text { Non-Diabetics } \\
\qquad n=193\end{array}$} \\
\hline & $3 a$ & $3 b$ & $3 b$ & & $3 a$ & $3 b$ & 4-5 & & $3 a$ & $3 b$ & 4-5 & \\
\hline & $\mathrm{n}=46$ & $\mathrm{n}=139$ & $\mathrm{n}=139$ & $p$ & $\mathrm{n}=18$ & $n=73$ & $n=93$ & $p$ & $n=28$ & $n=66$ & $\mathrm{n}=99$ & $p$ \\
\hline $\begin{array}{l}\text { Cardiovascular } \\
\text { disease }^{*}, \mathrm{n}(\%)\end{array}$ & 22 (48) & $80(58)$ & $137(71)$ & 0.002 & 7 (39) & 42 (58) & 76 (82) & $\begin{array}{c}< \\
0.001\end{array}$ & $15(54)$ & 38 (58) & $61(62)$ & 0.713 \\
\hline $\begin{array}{l}\text { Cardiac disease, } \\
\mathrm{n}(\%) \\
\text { Coronary artery } \\
\text { disease }\end{array}$ & $5(11)$ & $33(24)$ & $58(30)$ & 0.022 & $2(11)$ & $22(30)$ & 36 (39) & 0.062 & $3(11)$ & 11 (17) & $22(22)$ & 0.339 \\
\hline $\begin{array}{l}\text { Congestive } \\
\text { heart failure }\end{array}$ & $8(17)$ & 45 (32) & 102 (53) & $\begin{array}{c}< \\
0.001\end{array}$ & $2(11)$ & $26(36)$ & 59 (63) & $\begin{array}{c}< \\
0.001\end{array}$ & $6(21)$ & $19(29)$ & $43(43)$ & 0.040 \\
\hline $\begin{array}{l}\text { Severe valvular } \\
\text { heart disease }\end{array}$ & $2(4)$ & $3(2)$ & $10(5)$ & 0.371 & $1(6)$ & $1(1)$ & $5(5)$ & 0.375 & $1(4)$ & $2(3)$ & $5(5)$ & 0.805 \\
\hline $\begin{array}{l}\text { Cerebrovascular } \\
\text { disease, n (\%) }\end{array}$ & $10(22)$ & $32(23)$ & $54(28)$ & 0.475 & $2(11)$ & $16(22)$ & 34 (37) & 0.027 & $8(29)$ & $16(24)$ & $20(20)$ & 0.610 \\
\hline $\begin{array}{l}\text { Peripheral artery } \\
\text { disease, } \mathrm{n}(\%)\end{array}$ & $3(7)$ & $20(14)$ & $49(26)$ & 0.003 & $3(17)$ & 13 (18) & 30 (32) & 0.071 & 0 & $7(11)$ & 19 (19) & 0.022 \\
\hline
\end{tabular}

CKD etiology was considered unknown. However, in the absence of specific diagnostic tests and given the low biopsy rate of $4 \%$, the diagnostic certainty was low.

The prevalence of cardiovascular disease in our elderly CKD cohort was very high, present in $62 \%$ of the patients. Patients with CKD are more prone to develop cardiovascular disease ${ }^{15}$. Data available from several epidemiological studies revealed that cardiovascular events and cardiovascular mortality increased inversely with eGFR ${ }^{16,17}$. Conversely, cardiovascular disease is associated with increased risk of CKD progression ${ }^{18}$. Furthermore, the older the individual with CKD, the highest the risk of cardiovascular disease and mortality, and even more so if additional comorbid conditions including diabetes, hypertension, obesity, and other vascular risk factors are present ${ }^{19}$.

In our cohort, many established risk factors of cardiovascular disease showed a high prevalence; with an increase in the prevalence of cardiovascular disease with worse CKD stage (Table 3 and Figure 1). The cardiovascular disease burden associated with eGFR decline was pronounced in patients with diabetes (Table 3). The cardiovascular disease prevalence was higher than that reported from in European
CKD cohorts (German GCKD ${ }^{20}$, Spanish MERENA ${ }^{21}$, Italian CARHES ${ }^{22}$ ), even when adjusting for age.

Although our study was not designed to identify risk factors for CKD and for cardiovascular disease, several characteristics of the patients provided indirect evidence for several predisposing factors.

First, the diabetes prevalence of $50 \%$ is almost twice as high as in the PREVADIAB ${ }^{23}$, a populationbased study to evaluate the prevalence of diabetes in Portugal. Also, the prevalence of diabetes in our cohort was higher than that reported in other Europeans CKD cohorts (German GCKD ${ }^{20}$ : 35\%; Spanish MERENA ${ }^{21}$ : $41 \%$; Italian CARHES ${ }^{22}: 28 \%$ ), even when adjusting for age.

Among the traditional risk factors for CKD and for cardiovascular disease, the presence of hypertension in our cohort was almost universal $(96 \%)$, without significant differences between diabetic and non-diabetic patients. In terms of hypertension control, blood pressure was $<130 / 80 \mathrm{mmHg}$ in only approximately one-third of the patients. This gap between targets and clinical reality is consistent with other CKD cohort studies ${ }^{20-22}$, which illustrates the difficulties of blood pressure control in CKD, and a potential for improvement. A large percentage of patients were taking renin angiotensin 
system inhibitors $(70 \%)$, particularly men with diabetes $(77 \%)$. However, men with diabetes were the group with worst BP control, which may contribute to the role of male gender and diabetes in cardiovascular disease burden.

Current smoking was reported in $5 \%$ of the cohort, and former smoking in $21 \%$ (Table 1), with a male preponderance. This is a lower prevalence than that reported in the other CKD cohorts ${ }^{20-22,24}$.

Overall, 24\% of enrolled patients were obese (BMI $>30 \mathrm{~kg} / \mathrm{m}^{2}$ ), which is lower than the prevalence in other European CKD cohorts ${ }^{20-22}$. Therefore, obesity was not a major contributor to cardiovascular disease prevalence in our study group. Even so, obesity and overweight were more prevalent in diabetic patients.

Prediction of the renal and cardiovascular risks in people with CKD is likely to be improved by the incorporation of albuminuria into kidney disease staging $^{25}$. The data in our study regarding proteinuria was similar to that reported in other European CKD cohorts $^{21,22}$. On the other hand, the degree of proteinuria in our cohort is higher than other cohorts (CRIC) ${ }^{24}$, which may be related to the better BP control in those studies. The level of proteinuria was higher in patients with diabetes compared to patients without diabetes, confirming that proteinuria is a hallmark of diabetic nephropathy, but also an important contributor to the cardiovascular risk in diabetic patients.

Dyslipidemia is also a traditional cardiovascular risk factor that is frequently observed in CKD patients, with an increasing incidence with CKD progression $^{26}$. Dyslipidemia was very prevalent in our cohort $(85 \%)$ and more prevalent in patients with diabetes, which reinforces the cardiovascular risk in those patients.

Anemia is also an associated factor of cardiovascular disease prevalence and mortality, and CKD progression $^{27}$. The mean hemoglobin of the cohort was $12.1 \mathrm{~g} / \mathrm{dL}$, and the majority of the patients had hemoglobin greater than $11 \mathrm{~g} / \mathrm{dL}(74 \%)$. Since only $5 \%$ of the patients in the total cohort were receiving ESA therapy, the relatively high hemoglobin of the group as a whole cannot be attributed to overtreatment with these agents. Only $10 \%$ of the patients was receiving iron therapies, but transferrin saturation $<20 \%$ was documented in $38 \%$ of the patients, reflecting insufficient treatment with iron before nephrology referral.

CKD-mineral bone disorder is a major contributor to vascular calcification and cardiovascular disease ${ }^{28}$ in CKD patients. Concerning calcium-phosphorus and PTH levels, an evident finding was that only $19 \%$ of the patients in our cohort had PTH levels within the recommended targets based on K-DOQI guidelines ${ }^{29}$, despite good control of calcium-phosphorus levels. A very low percentage of patients receiving vitamin D and its analogues was found, suggesting that a further management optimization for CKD-mineral bone disorder is needed.

The prevalence of diabetes as well as other risk factors for CKD may partly explain international variation in CKD prevalence. In a recent narrative review on the factors that potentially underlie observed international differences in CKD prevalence in the elderly within Europe $^{30}$, the authors concluded that Portugal had the highest estimate of CKD prevalence, and the highest average score on CKD risk factors (i.e. diabetes mellitus, high blood pressure, physical inactivity, and salt intake).

The strengths of our study include the rigorous exploration of the first Portuguese CKD cohort with patients aged 65 years and over newly referred to a nephrology clinic. Furthermore, this was a representative group of patients, and knowing their baseline characteristics and cardiovascular morbidity will allow a better understanding of CKD epidemiology, nephrology referral policy in our geographical area, and the global approach to cardiovascular risk.

There are certain limitations to our research. First, this is a single-center study. Second, some misclassification bias maybe have been introduced based on the patients' self-reporting of comorbidity. Finally, because this cohort only comprised patients attending the nephrology outpatient clinic, our results may not necessarily translate to CKD patients who are not referred to nephrologists.

\section{Conclusions}

In summary, the characteristics of our referral CKD cohort demonstrated the heavy burden of cardiovascular risk profile and disease, and reflected an important role of several risk factors for kidney disease development. The prevalence of diabetes and cardiovascular disease is greater than other European CKD cohorts.

Lower eGFR level was associated with a greater burden of cardiovascular disease, highlighting the importance of strategically targeting cardiovascular risk reduction in these older patients. This is an important 
group of patients that should be characterized and understood; our results should improve management of these patients over time.

\section{SUPPLEMENTARY MATERIAL}

The following online material is available for this article:

Table S1 - Comparison of patients with diabetes mellitus (DM) with and without presumed diabetic nephropathy $(\mathrm{DN})$ and patients without diabetes mellitus

\section{References}

1. Jha V, Garcia-Garcia G, Iseki K, Li Z, Naicker S, Plattner B, et al. Chronic kidney disease: global dimension and perspectives. Lancet 2013;382:260-72.

2. Saran R, Li Y, Robinson B, Ayanian J, Balkrishnan R, Bragg-Gresham J, et al. US Renal Data System 2014 Annual Data Report: Epidemiology of Kidney Disease in the United States. Am J Kidney Dis 2015;66:Svii,S1-305.

3. Pippias M, Stel VS, Abad Diez JM, Afentakis N, Herrero-Calvo JA, Arias M, et al. Renal replacement therapy in Europe: a summary of the 2012 ERA-EDTA Registry Annual Report. Clin Kidney J 2015;8:248-61.

4. Kramer A, Pippias M, Stel VS, Bonthuis M, Abad Diez JM, Afentakis N, et al. Renal replacement therapy in Europe: a summary of the 2013 ERA-EDTA Registry Annual Report with a focus on diabetes mellitus. Clin Kidney J 2016;9:457-69.

5. Substitutive Renal Therapy of Chronic Renal Disease in Portugal. [cited 2017 Jun 30]. Available from: http:www.spnefro.pt/ comissoes_Gabinete_registo_2016/registo_2016

6. McCullough PA. Cardiorenal risk: an important clinical intersection. Rev Cardiovasc Med 2002;3:71-6.

7. O'Hare AM, Choi AI, Bertenthal D, Bacchetti P, Garg AX, Kaufman JS, et al. Age affects outcomes in chronic kidney disease. J Am Soc Nephrol 2007;18:2758-65.

8. Dalrymple LS, Katz R, Kestenbaum B, Shlipak MG, Sarnak MJ, Stehman-Breen C, et al. Chronic kidney disease and the risk of end-stage renal disease versus death. J Gen Intern Med 2011;26:379-85.

9. Santos J, Fonseca I, Malheiro J, Beirao I, Lobato L, Oliveira $\mathrm{P}$, et al. End-stage renal disease versus death in a Portuguese cohort of elderly patients: an approach using competing event analysis. J Investig Med 2017;65:1041-8.

10. Levey AS, Stevens LA, Schmid CH, Zhang YL, Castro AF 3rd, Feldman HI, et al.; CKD-EPI (Chronic Kidney Disease Epidemiology Collaboration). A new equation to estimate glomerular filtration rate. Ann Intern Med 2009;150:604-12.

11. Folstein MF, Folstein SE, McHugh PR. "Mini-mental state". A practical method for grading the cognitive state of patients for the clinician. J Psychiatr Res 1975;12:189-98.

12. Charlson ME, Pompei P, Ales KL, MacKenzie CR. A new method of classifying prognostic comorbidity in longitudinal studies: development and validation. J Chronic Dis 1987;40:37383.

13. Levey AS, Coresh J. Chronic kidney disease. Lancet 2012;379:165-80.

14. Eckardt KU, Coresh J, Devuyst O, Johnson RJ, Köttgen A, Levey AS, et al. Evolving importance of kidney disease: from subspecialty to global health burden. Lancet 2013;382:158-69.
15. Herzog CA, Asinger RW, Berger AK, Charytan DM, Díez J, Hart RG, et al. Cardiovascular disease in chronic kidney disease. A clinical update from Kidney Disease: Improving Global Outcomes (KDIGO). Kidney Int 2011;80:572-86.

16. Go AS, Chertow GM, Fan D, McCulloch CE, Hsu CY. Chronic kidney disease and the risks of death, cardiovascular events, and hospitalization. N Engl J Med 2004;351:1296-305.

17. van der Velde M, Matsushita K, Coresh J, Astor BC, Woodward M, Levey A, et al. Lower estimated glomerular filtration rate and higher albuminuria are associated with all-cause and cardiovascular mortality. A collaborative meta-analysis of high-risk population cohorts. Kidney Int 2011;79:1341-52.

18. Levin A, Djurdjev O, Barrett B, Burgess E, Carlisle E, Ethier J, et al. Cardiovascular disease in patients with chronic kidney disease: getting to the heart of the matter. Am J Kidney Dis 2001;38:1398-407.

19. Collins AJ, Li S, Gilbertson DT, Liu J, Chen SC, Herzog CA. Chronic kidney disease and cardiovascular disease in the Medicare population. Kidney Int Suppl 2003:S24-31.

20. Titze S, Schmid M, Köttgen A, Busch M, Floege J, Wanner C, et al. Disease burden and risk profile in referred patients with moderate chronic kidney disease: composition of the German Chronic Kidney Disease (GCKD) cohort. Nephrol Dial Transplant 2015;30:441-51.

21. Martínez-Castelao A, Górriz JL, Portolés JM, De Alvaro F, Cases A, Luño J, et al. Baseline characteristics of patients with chronic kidney disease stage 3 and stage 4 in Spain: the MERENA observational cohort study. BMC Nephrol 2011;12:53.

22. De Nicola L, Donfrancesco C, Minutolo R, Lo Noce C, Palmieri L, De Curtis A, et al. Prevalence and cardiovascular risk profile of chronic kidney disease in Italy: results of the 2008-12 National Health Examination Survey. Nephrol Dial Transplant 2015;30:806-14.

23. Gardete-Correia L, Boavida JM, Raposo JF, Mesquita AC, Fona $\mathrm{C}$, Carvalho R, et al. First diabetes prevalence study in Portugal: PREVADIAB study. Diabet Med 2010;27:879-81.

24. Lash JP, Go AS, Appel LJ, He J, Ojo A, Rahman M, et al. Chronic Renal Insufficiency Cohort (CRIC) Study: baseline characteristics and associations with kidney function. Clin J Am Soc Nephrol 2009;4:1302-11.

25. Chronic Kidney Disease Prognosis Consortium; Matsushita K, van der Velde M, Astor BC, Woodward M, Levey AS, de Jong $\mathrm{PE}$, Coresh J, et al. Association of estimated glomerular filtration rate and albuminuria with all-cause and cardiovascular mortality in general population cohorts: a collaborative meta-analysis. Lancet 2010;375:2073-81.

26. Kidney Disease Outcomes Quality Initiative (K/DOQI) Group. $\mathrm{K} / \mathrm{DOQI}$ clinical practice guidelines for management of dyslipidemias in patients with kidney disease. Am J Kidney Dis 2003;41:I-IV,S1-91.

27. Thorp ML, Johnson ES, Yang X, Petrik AF, Platt R, Smith DH, et al. Effect of anaemia on mortality, cardiovascular hospitalizations and end-stage renal disease among patients with chronic kidney disease. Nephrology (Carlton) 2009;14:240-6.

28. Drüeke TB, Massy ZA. Atherosclerosis in CKD: differences from the general population. Nat Rev Nephrol 2010;6:723-35.

29. National Kidney Foundation. K/DOQI clinical practice guidelines for bone metabolism and disease in chronic kidney disease. Am J Kidney Dis 2003;42:S1-201.

30. Stel VS, Brück K, Fraser S, Zoccali C, Massy ZA, Jager KJ. International differences in chronic kidney disease prevalence: a key public health and epidemiologic research issue. Nephrol Dial Transplant 2017;32:ii129-ii135. 